\title{
INDONESIA IN SUPPORTING THE ECONOMY AND HEALTH FOR THE COMMUNITY IN THE NEW NORMAL ERA
}

\author{
Hardini Ariningrum, S.E., M.Ak, Dr. Harmani Harun, S.E., M.M., akt, Murni \\ Indah Sari , Eka Nur Rahmawati \\ Faculty of Economics \\ Malahayati University Bandar Lampung \\ hardini@malahayati.co.id, harmani.jkt24@gmail.com, murniindahsari1213@gmail.com. \\ rahma090801@gmail.com
}

\begin{abstract}
This study aims to analyze the role of the Indonesian government in handling Covid19 in the health and economy of the Indonesian people under the new normal. The research method used is descriptive qualitative and quantitative methods, using research results, references and online news sources that are directly related to this research. The Covid19 pandemic has affected the world, and Indonesia is one of them. Indonesia is fighting Covid-19 by modifying its regional isolation (lockdown) policy into large-scale social restrictions (PSBB), which are applied locally based on the severity of the province, district, or city. In addition, along with the increasing number of cases of the new variant of the COVID-19 virus from July 26 to August 2, 2021, the Indonesian government has begun to continue its policies to eradicate the corona virus and implement restrictions on community activities (PPKM). PPKM is extended for each blood differently. For regions, especially Lampung, it was extended from 10 to 23 August 2021. The COVID19 pandemic requires the government to formulate extraordinary policies. Addressing health problems, protecting the public through social security and protecting business policies are the top priorities. Budget reallocation, reorientation of activities and adjustment of mandatory spending are the main ways the government provides funds to respond to the needs of COVID-19. On the other hand, pseudo growth also refers to the challenges that the economy may face in the second half of 2021, due to the implementation of emergency PPKM and level 4 caused by the Delta variant.
\end{abstract}

Keywords: Handling Covid-19, Government Policy in Public Health, and Indonesia's Economic Growth.

\section{Preliminary}

The COVID-19 pandemic in Indonesia was first detected on March 2, 2020, when two people were confirmed to have contracted it from a Japanese citizen. By April 9, the pandemic had spread to 34 provinces. East Java, DKI Jakarta and South Sulawesi were the most exposed provinces. Efforts to prevent the spread were carried out and campaigned. There are at least 2 ways that are the key to controlling the transmission and spread of COVID-19, namely by maintaining distance and diligently washing hands with soap and increasing portable sinks which are held independently by the people. The government has finally implemented Large-Scale Social Restrictions (PSBB) and campaigned for Stay at home and coupled with the Implementation of Restrictions on Community Activities (PPKM) are the policies of the Indonesian Government since the new year 2020 until August 23, 2021 to deal with the Covid-19 pandemic in Indonesia.

Because in July Indonesia experienced a spike in cases of the Covid-19 virus with the arrival of the Delta variant of the Covid virus, the Government carried out a policy in the Enforcement of Restrictions on Community Activities, President Jokowi appointed Coordinating Minister for Maritime Affairs and Investment Luhut Binsar Pandjaitan as 
the coordinator for implementing the emergency PPKM. Coordinating Minister for Maritime Affairs and Investment Luhut B. Pandjaitan together with Coordinating Minister for the Economy Airlangga Hartarto announced the Policy for Enforcement of Community Activity Restrictions (PPKM) Levels 4 and 3 from 26 July to 2 August 2021 through a press conference held virtually on Sunday (25 July 2021).

The COVID-19 pandemic requires the government to have extraordinary policies. Policies to deal with health problems, protect the public with social security, and protect the business world are his priorities. Budget reallocation, refocusing of activities, as well as adjustments to the amount of mandatory spending are the government's main ways to fund the needs of handling COVID-19.

The policies that have been carried out by the government for the health sector are as follows.

1. IDR 65.8 trillion for health care spending

2. Rp5.9 trillion for incentives for central and local media personnel

3. Rp300 billion for death compensation for health workers (Rp300 million/person);

4. Rp3 trillion is allocated to the contribution subsidy for tariff adjustments for NonWage Recipients and Non-Employees in accordance with Presidential Regulation 75 of 2019.

5. The government also provides a budget allocation for the cost of treating Covid19 patients which is centralized through the Ministry of Health.

6. Providing tax facilities for goods and services needed in handling the Covid-19 pandemic

7. Relaxation of provisions on the import of medical devices for the purpose of handling COVID-19 in the form of exemption from distribution permit obligations or the Special Access Scheme (SAS).

The pattern of quarterly construction activity during 2020 the first quarter of 20201 shows fluctuations in the number of workers, remuneration and wages of workers, the value of construction work, business conditions and prospects, as well as construction business problems. The Permanent Workers Index in the first quarter of 2021 decreased by 1.24 percent compared to the first quarter of 2020. The Remuneration and Wages Index in the first quarter of 2021 decreased by 3.92 percent compared to the first quarter of 2020 . The Construction Value Index Completed in the first quarter of $2021 \mathrm{I}$ in 2021 decreased by 2.89 percent compared to the first quarter of 2020 .

During the 2020 period, the majority of entrepreneurs were pessimistic about their business conditions in the first quarter of 2020 and the second quarter of 2020. This is reflected in the values of the Business Conditions Index and Business Prospects Index which are smaller than 50. The index of business conditions and prospects in the first quarter of this year 2020 of 39.11 and 47.12 .

Meanwhile, in the 2021 period, the majority of entrepreneurs are pessimistic about their business conditions in the first quarter of 2021, but are optimistic that their business conditions in the second quarter of 2021 will have better prospects. This is reflected in the value of the Business Condition Index which is less than 50 and the Business Prospect Index which is more than 50. The value of the business condition and prospect index in the first quarter of 2021 is 42.13 and 53.00.

\section{Literature Review}

At the beginning of the lock down incident of the city of Wuhan using various reported incidents, it had a negative impact on news and business interactions for residents and networks of the city of Wuhan, Hubei Province, China and also when the virus spread throughout mainland China. The policy taken later was a lockdown, where residents were required to continue to stay at home in order to suppress the spread of COVID-19. There are no activities carried out outside the home, except very forced. This gradually also has 
an impact on the economy, whose activities have decreased because there are no activities that are allowed to be done outside the home.

The decline in China's economy caused by the COVID-19 pandemic will of course also have an impact on the global economy, considering that China is the second largest economy in the world. Several credible research institutions in the world have predicted how the spread of this epidemic will affect the global economy. For Indonesia, Finance Minister Sri Mulyani Indrawati predicts that economic growth during this outbreak could reach minus $0.4 \%$ for the worst possible case. Especially at this time, not only China is affected by the virus, but almost the whole world is also feeling it, including Indonesia. This then makes economic growth even more worrying. Although several cities in several countries have implemented a new normal system, by carrying out activities outside the home while still adhering to health protocols, in fact there are still many places that have not enforced it, so that the economy can be said to be unstable.

There are many forms of efforts that have been called and carried out by the world to reduce and stop the spread of this epidemic. One form of this effort is to do social distancing or physical distancing. Social distancing itself is one of the steps to prevent and control Corona virus infection by encouraging healthy people to limit visits to crowded places and direct contact with other people. Some examples of the implementation of social distancing that are commonly carried out are such as 1) working from home (work from home), 2) online learning at home for school and university students, 3) postponing meetings or events that are attended by many people, such as conferences, seminars, and meetings, or do it online via video conferencing or teleconference and 4) not visiting people who are sick, but simply by telephone or video call.

With the government's policy in controlling Covid-19, Indonesia itself has implemented a Large-Scale Social Enforcement (PSBB) policy, for the first time implementing the PSBB policy in DKI Jakarta Province which was approved on April 6, 2020 which is valid for two weeks until April 23, 2020. In addition, in the case of July 2021, Indonesia anticipated a spike in Covid-19 with the Delta variant virus, the Indonesian government implemented a policy of Enforcement of Community Activity Restrictions (PPKM) which began to be implemented from July 26 to August 2, 2021. With this PPKM, the Coordinating Minister for Maritime Affairs of the Republic of Indonesia explained several regulations related to market opening, small industry, technical opening of food stalls, and public transportation operations.

In the health sector, the Indonesian government's policy is to vaccinate against Covid-19. According to the Ministry of Health, Terawan Agus Putranto in the Financial Note Press Conference which was held online and offline on August 14, 2020 at the Ministry of Finance, Jakarta. Get a budget for the post of economic recovery of Rp. 25.40 trillion which is used for the procurement of COVID-19 vaccine, immunization, facilities and infrastructure and health research and development as well as BPJS contribution assistance reserves for PBPU/BP. The Ministry of Health's budget for 2021 is Rp. This 84.3 trillion is in addition to the additional Rp. 25.4 trillion for the preparation of vaccines and for national health security. For the first time the name of vaccination in Indonesia is the Sinovac vaccine type.

This Sinovac vaccine is to prevent infection with the SARS-CoV-2 or COVID-19 virus. The Sinovac vaccine, also known as CoronaVac, has received an emergency use permit from the Indonesian Food and Drug Administration (BPOM). The vaccination will last for 15 months and will take place in 2 periods, namely Period 1 which will run from January to April 2021, prioritizing 1.3 million health workers and 17.4 million public officers in 34 provinces. Period 2 lasts for 11 months, from April 2021 to March 2022 to reach a population of up to 181.5 million people. 
Vol. 1, No. 1, 67-77

\section{Methodology}

The research method used is descriptive qualitative method, using secondary data sources based on research results, references \& online coverage that are directly related to this research. The data analysis method is in the form of secondary data in the form of qualitative and quantitative data according to journals and online news. Secondary data is data that refers to news collected from existing sources, obtained according to research results, references and online news.

\section{Results And Discussion}

\section{Policy Modifications in Facing Covid-19}

Various countries have implemented regional quarantine (lockdown) policies to limit the total spread of this virus. However, changing people's social behavior is not an easy job. Various countries with all their limitations are experiencing obstacles that are not simple, even developed countries in Europe and the United States are very overwhelmed. The general policy that requires people to carry out social and physical distancing (maintaining a safe distance between individuals and avoiding crowds) is not something easy for humans on earth who are already accustomed to social behavior.

The regional quarantine (lockdown) policy was then modified in such a way by various countries. Some apply fully, partially, or locally and to a minimum. Indonesia itself modified it with the name of Large-Scale Social Restrictions (PSBB) which were applied per region, either province or district/city based on the severity of the outbreak whose assessment was determined by the central government through the Ministry of Health. The PSBB implementation rules are regulated through Government Regulation (PP) Number 21 of 2020 concerning Large-Scale Social Restrictions. In addition, the rules regarding PSBB are also regulated in Presidential Decree (Keppres) No. 11 of 2020 concerning the Determination of Public Health Emergency. The PP and Presidential Decree were signed by President Joko Widodo on March 31, 2020.

In addition, the modification of the Indonesian government's policy in anticipating the Covid-19 virus, the Delta variant, issued a circular regarding the policy for the Enforcement of Community Activity Restrictions (PPKM) which will be implemented from 26 July to 2 August 2021. With this PPKM, the Coordinating Minister for Maritime Affairs of the Republic of Indonesia explained several regulations related to market opening, small industry, technical opening of food stalls, and public transportation operations. For the adjustment of the PPKM that applies by implementing health protocols to break the chain of transmission of the Covid-19 virus, the Indonesian government has adjusted the level four and level three PPKM.

\section{PPKM Level Four Adjustment Regulations}

According to the Coordinating Minister for Maritime Affairs of the Republic of Indonesia, markets that sell basic necessities are allowed to open as usual with strict health protocols, People's Markets that sell other than basic necessities can be opened with a maximum capacity of 50 percent until 15.00 , Then, street vendors, grocery stores, agents or voucher outlets, Barbershops, Laundry, Street Vendors, Small Workshops, Car Washes, and other similar small businesses are allowed to open with strict health protocols until $21.00 \mathrm{WIB}$ with technical arrangements regulated by the Regional Government.

Then, food stalls, street vendors, hawker stalls and the like that have their place of business in an open space are allowed to open with strict health protocols until 20.00 and the maximum meal time for each visitor is 20 minutes.Meanwhile, public transportation (public vehicles, mass transportation, taxis (conventional and online) and rental or rental 
vehicles) is implemented with a maximum capacity setting of 50 percent (fifty percent) by implementing stricter health protocols.

\section{Level Three PPKM Adjustment Conditions}

For the 33 cities/regencies that are within the level 3 zone, the provisions include, among others, that the export industry and its supporting industries can operate by shift arrangement, each shift being filled with a maximum of 50 percent of the total workforce. strict health protocol. On the 3rd floor, the people's market that sells non-essential materials can be opened with a maximum capacity of 50 percent until 15.00 WIB. Small industries such as street vendors, grocery stores, and others are still allowed to open by implementing strict health protocols until $20.00 \mathrm{WIB}$, technical arrangements and supervision are delegated to the Regional Government. The same provisions for opening hours are also provided for food stalls, street vendors, hawker stalls and the like with strict procedures until 20.00 local time. Diners are allowed to eat at the place a maximum of 25 percent of capacity and a maximum meal time of 30 minutes. Malls can operate up to 25 percent until 17.00 WIB," added Coordinating Minister Luhut. The implementation of non-public infrastructure development activities can operate with a maximum of 10 workers.

While the provisions for places of worship, in the PPKM Level 3 area, residents are allowed to hold worship or religious activities in congregation during the implementation period with a maximum capacity of 25 percent or 20 people by implementing strict health protocols. Furthermore, for public transportation, including taxis and conventional and online rental vehicles, it can be applied with a maximum capacity of 70 percent. Wedding receptions can be held with a maximum of 20 guests and do not dine on site.

\section{Indonesian Government Policies in the Public Health Sector}

The COVID-19 pandemic requires the government to have extraordinary policies. Policies to deal with health problems, protect the public with social security, and protect the business world are his priorities. Budget reallocation, refocusing of activities, as well as adjustments to the amount of mandatory spending are the government's main ways to fund the needs of handling COVID-19.

The policies that have been carried out by the government for the health sector are as follows:

1. IDR 65.8 trillion for health care spending:

- Medical devices (PPE, test kits, reagents, ventilators, hand sanitizers, etc.).

- Health facilities and infrastructure, including upgrading 132 referral hospitals for handling Covid-19 patients, including the Wisma Atlet.

- Human Resources Support.

2. Rp5.9 trillion for incentives for central and local media personnel:

- Central medical personnel of Rp. 1.3 trillion and regional medical personnel of Rp. 4.6 trillion;

- Incentives for doctors (specialists Rp. 15 million/month), general practitioners (Rp. 10 million/month), nurses (Rp.7.5 million/month), and other health workers (Rp 5 million/month). Given for 6 months.

- Budget requirements for incentives for medical personnel are calculated only for medical personnel at the Central Hospital, KKP satker, BTKL and Balitbangkes, including those on duty at Wisma Atlet Hospital.

- The budget for incentives will be shared by the Central and Regional Governments, including using the DAK Non-Physical Health from Health Operational Costs and APBD.

3. Rp300 billion for death compensation for health workers (Rp300 million per person). 
4. Rp3 trillion is allocated to the contribution subsidy for tariff adjustments for NonWage Recipients and Non-Employees in accordance with Presidential Regulation 75 of 2019.

5. The government also provides a budget allocation for the cost of treating Covid19 patients which is centralized through the Ministry of Health. All maintenance costs are borne by the government according to standard handling costs. Standard treatment costs include a complete package, ranging from doctor fees to the cost of repatriating the body if the patient dies. Funding for Covid-19 patients is taken from the 2020 State Budget and Regional Budget.

6. Providing tax facilities for goods and services needed in handling the Covid-19 pandemic:

- VAT is borne by the government for government agencies/agencies, referral hospitals, or other parties appointed to assist the handling of COVID-19 on the import, acquisition, and/or utilization of goods and services for the handling of COVID-19, valid April s.d. September 2020.

- Exemption of PPh 22 Import and/or PPh 22 on imports and/or purchases of goods for handling COVID-19 carried out by government agencies/agencies, referral hospitals, or other parties appointed to assist in handling COVID-19, valid from April to d. September 2020.

- Exemption of PPh 22 on the sale of goods for handling COVID-19 to government agencies/agencies, referral hospitals, or other parties appointed to assist the handling of COVID-19, valid April s.d. September 2020.

- Exemption of PPh 21 for domestic individual taxpayers who receive compensation from government agencies/agencies, referral hospitals, or other parties appointed for COVID-19 handling services.

- The exemption of $\mathrm{PPh} 23$ for domestic corporate taxpayers and business forms that receive compensation from government agencies/agencies, referral hospitals, or other parties appointed for technical services, management, consultants, or other services needed in handling COVID19, applies April sd September 2020.

7. Relaxation of provisions on the import of medical devices for the purpose of handling COVID-19 in the form of exemption from distribution permit obligations or the Special Access Scheme (SAS).

In addition, there is a public health policy carried out by the Indonesian government, namely the Covid-19 vaccination. According to the Ministry of Health, Terawan Agus Putranto in the press conference on the Financial Note which was held boldly and attractively on August 14, 2020 at the Ministry of Finance, Jakarta. Get a budget for the post of economic recovery of Rp. 25.40 trillion which is used for the procurement of COVID-19 vaccine, utilization, facilities and infrastructure and health research and development as well as assistance for BPJS contributions for PBPU/BP.

The Ministry of Health's budget for 2021 is Rp. This 84.3 trillion is in addition to the additional Rp. 25.4 trillion for the preparation of vaccines and for national health security. The name of the vaccination in Indonesia for the first time is the Sinovac vaccine type.

This Sinovac vaccine is to prevent infection with the SARS-CoV-2 or COVID-19 virus. The Sinovac vaccine, also known as CoronaVac, has received an emergency use permit from the Indonesian Food and Drug Administration (BPOM). The implementation will last for 15 months and will take place in 2 periods, Period 1 runs from January to April 2021 by prioritizing 1.3 million health workers and 17.4 million public officers in 34 provinces. Period 2 lasts for 11 months, from April 2021 to March 2022 to reach a population of up to 181.5 million people.

Program vaksinasi COVID-19 di Indonesia mulai dilakukan oleh pemerintah, pada Rabu 13 Januari pagi di Istana Negara. Orang yang pertama kali disuntik vaksin buatan Sinovac

The $1^{\text {st }}$ Conference On Public Health and Medical Sciences (ICOPHMEDS) 2021 
adalah Presiden Joko Widodo. Pada saat yang sama, sejumlah pejabat, tokoh agama, organisasi profesi serta perwakilan masyarakat turut mengikuti vaksinasi.

The President goes through four stages when he receives an injection of the COVID-19 vaccine. First, data registration and verification are carried out at Table 1 (one), screening in the form of anamnesis and a simple physical examination at Table 2 (two) by checking blood pressure and body temperature. At Table 3 the President received an injection of the COVID-19 vaccine injected by the vaccinator Prof. dr. Abdul Muttalib who is the presidential doctor. After being vaccinated, the President went to Table 4 for recording, and had to wait for 30 minutes to anticipate any Adverse Events after Immunization (AEFI). As the recipient of the vaccine, the President was also given a vaccination card and education on COVID-19 prevention, as well as the implementation of health checks before vaccination for all Indonesian people.

\section{The Impact of the Indonesian Economy During a Pandemic}

The decline in China's economy caused by the COVID-19 pandemic will of course also have an impact on the global economy, considering that China is the second largest economy in the world. Several credible research institutions in the world have predicted how the spread of this epidemic will affect the global economy. For Indonesia, Finance Minister Sri Mulyani Indrawati predicts that economic growth during this outbreak could reach minus $0.4 \%$ for the worst possible case. Especially at this time, not only China is affected by the virus, but almost the whole world is also feeling it, including Indonesia. This then makes economic growth even more worrying. Although several cities in several countries have implemented a new normal system, by carrying out activities outside the home while still adhering to health protocols, in fact there are still many places that have not enforced it, so that the economy can be said to be unstable.

With regulations to reduce the spike in Covid-19 cases, such as PSBB and PPKM, this has an impact on buying and selling in the manufacturing, transfer and tourism zones, experiencing a decline. This situation is very worrying, considering the number of dependents that must be borne, such as paying for electricity, paying employees and so on. The tourism industry is one of the companies affected by the spread of this virus. The chairman of the Bali Tourism Board (BTB) of the Association of Indonesian Tourism Industries (GIPI) Bali, Ida Bagus Agung Partha Adnyana, suggested the alleged birth of 40,000 lodgings with the failure to earn IDR 1 trillion every month (Kontan, 5 March 2020).

The decline in the tourism sector has had a domino effect on the Micro, Small and Medium Enterprises (MSME) zone. Based on evidence carried out by P2E LIPI, the effect of the decline in tourism on MSMEs engaged in micro-food and beverage services reached $27 \%$. Meanwhile, the impact on small food and beverage services was $1.77 \%$, and medium enterprises was at $0.07 \%$. The influence of the Covid-19 virus on activities since wood and rattan, micro-enterprises will be at $17.03 \%$. For small services in the wood and rattan activity zone 1.77 medium enterprises $0.01 \%$. Meanwhile, household targets will also be corrected between $0.5 \%$ to $0.8 \%$ (katadata.co.id, March 2, 2020). Whereas the economic progress of a country is very dependent on the tolerance of Micro, Small and Medium Enterprises when facing a crisis.

Although it is known that its resilience in the face of economic crises, related to the latest issue of the General Chair of the Indonesian Micro, Small and Medium Enterprises Association (Akumindo) Ikhsan Ingrabatun estimates that the turnover of MSMEs in the non-culinary zone has fallen by $3035 \%$ since Covid-19, the reason is that sales of these products rely on face-to-face. or a physical meeting between entrepreneurs and consumers. MSMEs that trade non-culinary commodities refer to foreign tourists such as markets (Kompas, 10 March 2020). The presence of the corona virus (covid-19) has made economic conditions throughout the country worse. The COVID-19 pandemic is expected to affect the misery that spreads to formal and informal sector organizers. More than 1.5 million workers have been laid off or laid off. 
Micro, Small and Medium Enterprises that are able to survive in the midst of the COVID19 climate include MSMEs that are already connected to the digital ecosystem by utilizing the marketplace in Indonesia. And MSMEs that are able to survive in the era of the covid-19 pandemic are MSMEs that are able to adapt their business with innovative products, for example, those that previously sold bags and clothes products then changed their products to selling cloth masks. Other industries that are able to survive during the COVID-19 pandemic are industries related to meeting basic needs including electricity, clean water, agriculture, animal husbandry, plantations, fisheries, automotive and banking. Likewise, the retail industry is able to survive, this is because some take advantage of sales through digital marketing.

\section{Indonesia's Economic Growth in July 2021}

1. The Indonesian economy based on the amount of Gross Domestic Product (GDP) based on current prices in the second quarter of 2021 reached Rp4,175.8 trillion and at constant prices in 2010 reached Rp2,772.8 trillion.

2. Indonesia's economy in the second quarter of 2021 compared to the previous quarter grew by 3.31 percent (q-to-q). In terms of production, the Agriculture, Forestry and Fisheries Business Fields experienced the highest growth of 12.93 percent. Meanwhile, in terms of expenditure, the Government Consumption Expenditure Component (PK-P) experienced the highest growth of 29.07 percent.

3. Indonesia's economy in the second quarter of 2021 compared to the second quarter of 2020 grew by 7.07 percent (y-on-y). In terms of production, the Transportation and Warehousing Business Field experienced the highest growth of 25.10 percent. From the expenditure side, the Export Component of Goods and Services experienced the highest growth of 31.78 percent.

4. The Indonesian economy in the first semester of 2021 compared to the first semester of 2020 grew by 3.10 percent (c-to-c). In terms of production, the largest growth occurred in the Information and Communication Business Field of 7.78 percent. Meanwhile, in terms of expenditure, all components grew, the highest growth occurred in the Export Component of Goods and Services at 18.51 percent.

5. Growth (y-on-y) in the second quarter of 2021 occurred in all island groups. This is especially evident in the group of provinces in Java, with a contribution of 57.92 percent, and growth (y-on-y) of 7.88 percent.

According to the Coordinating Minister for Economic Affairs of the Republic of Indonesia, Airlangga continued that there are several main strategies that will continue to be carried out by the Government, namely:

1. Handling Covid-19 through intensification of vaccinations in order to reduce the spike in cases and reduce mortality, and 73 million doses have been prepared in August 2021. The government also continues to coordinate more intensively with all relevant stakeholders to achieve herd immunity.

2. Optimizing the implementation of PPKM to support the effectiveness of vaccination. The implementation of PPKM is carried out based on the classification of the risk of spreading in each region, so that the rate of addition of cases can be suppressed more quickly and the risk of slowing down the economy can be minimized.

3. Encouraging community participation in the success of the vaccination program and increasing mutual adherence to health protocols and PPKM policies.

All of the Government's efforts to control the spread of Covid-19 are expected to immediately restore the momentum of economic recovery. Counter policies implemented by the Government and a higher level of adaptation to community activities will keep the growth in Quarter III-2021 from falling too deep. In addition, the economic recovery of Indonesia's main trading partners will provide a boost to higher export demand. The 
potential for normalizing public consumption after the easing of the PPKM will also spur a better economic recovery in Quarter IV-2021.

\section{Conclusion}

Various countries with all their limitations are experiencing obstacles that are not simple, even developed countries in Europe and the United States are very overwhelmed. The general policy that requires people to practice social and physical distancing is not something easy for humans on earth who are already accustomed to social behavior. Some apply fully, partially, or locally and to a minimum. Indonesia itself modifies it with the name Large-Scale Social Restrictions which are applied per region, either province or district/city based on the severity of the outbreak whose assessment is determined by the central government through the Ministry of Health.

In addition, the modification of the Indonesian government's policy in anticipating the Covid-19 virus, the Delta variant, issued a circular regarding the policy for the Enforcement of Restrictions on Community Activities which will be implemented from July 26 to August 2, 2021. To adjust the PPKM that applies by implementing health protocols to break the chain of transmission of the Covid virus -19, the Indonesian government made adjustments to PPKM level four and level three. The COVID-19 pandemic requires the government to have extraordinary policies. The budget requirements for incentives for medical personnel are calculated only for medical personnel at the Central Hospital, KKP satker, BTKL and Balitbangkes, including those on duty at the Wisma Atlet Hospital. It also provides a budget allocation for the cost of treating Covid-19 patients which is centralized through the Ministry of Health.

The decline in China's economy caused by the COVID-19 pandemic will of course also have an impact on the global economy, considering that China is the second largest economy in the world. For Indonesia, Finance Minister Sri Mulyani Indrawati predicts that economic growth during this outbreak could reach minus $0.4 \%$ for the worst possible case. Especially at this time, not only China is affected by the virus, but almost the whole world is also feeling it, including Indonesia. Although several cities in several countries have implemented a new normal system, by carrying out activities outside the home while still adhering to health protocols, in fact there are still many places that have not enforced it, so that the economy can be said to be unstable. This situation is very worrying, considering the number of dependents that must be borne, such as paying for electricity, paying employees and so on. The tourism industry is one of the companies affected by the spread of this virus. Based on evidence carried out by P2E LIPI, the effect of the decline in tourism on MSMEs engaged in micro-food and beverage services reached $27 \%$. For small services in the wood and rattan activity zone 1.77 medium enterprises $0.01 \%$.

MSMEs that trade non-culinary commodities refer to foreign tourists such as markets. The COVID-19 pandemic is expected to affect the misery that spreads to formal and informal sector organizers. Micro, Small and Medium Enterprises that are able to survive in the midst of the COVID-19 climate include MSMEs that are already connected to the digital ecosystem by utilizing the marketplace in Indonesia. And MSMEs that are able to survive in the era of the covid-19 pandemic are MSMEs that are able to adapt their business with innovative products, for example, those that previously sold bags and clothes products then changed their products to selling cloth masks.

Other industries that are able to survive during the COVID-19 pandemic are industries related to meeting basic needs including electricity, clean water, agriculture, animal husbandry, plantations, fisheries, automotive and banking. Likewise, the retail industry is able to survive, this is because some take advantage of sales through digital marketing. Indonesia based on the amount of Gross Domestic Product at current prices in the second quarter of 2021 reached IDR 4,175.8 trillion and at constant prices in 2010 it reached IDR 
$2,772.8$ trillion. Indonesia in the second quarter of 2021 compared to the previous quarter experienced a growth of 3.31 percent. Meanwhile, in terms of expenditure, the Government Consumption Expenditure Component experienced the highest growth of 29.07 percent.

Indonesia in the second quarter of 2021 against the second quarter of 2020 experienced a growth of 7.07 percent. Indonesia in the first semester of 2021 against the first semester of 2020 experienced a growth of 3.10 percent. This is especially evident in the group of provinces in Java, with a contribution of 57.92 percent, and growth of 7.88 percent. The government also continues to coordinate more intensively with all relevant stakeholders to achieve herd immunity. The implementation of PPKM to support the effectiveness of vaccination. Counter policies implemented by the Government and a higher level of adaptation to community activities will keep the growth in Quarter III-2021 from falling too deep. In addition, the economic recovery of Indonesia's main trading partners will provide a boost to higher export demand.

The potential for normalizing public consumption after the easing of the PPKM will also spur a better economic recovery in Quarter IV-2021.

\section{REFERENCES}

Rosita, Rahmi. "Pengaruh pandemi Covid-19 terhadap UMKM di Indonesia." Jurnal Lentera Bisnis 9.2 (2020): 109-120.

Arianto, Bambang. "Pengembangan UMKM Digital di Masa Pandemi Covid19." ATRABIS: Jurnal Administrasi Bisnis (e-Journal) 6.2 (2020): 233-247.

(Hafizah, Gia Dara. "Peran Ekonomi dan Keuangan Syariah pada Masa Pandemi COVID-19." LIKUID: Jurnal Ekonomi Industri Halal 1.1 (2021).

Investasi, K. K. (2021, Juli 25). PPKM Level Empat dan Tiga Diberlakukan Mulai 26 Juli-2Agustus 2021. Dipetik Agustus 23, 2021, dari maritim.co.id: https://maritim.go.id/ppkm-level-empat-tiga-diberlakukan-mulai-26-juli-2/

AloDokter. (2021, Maret 16). alodokter.com. Dipetik Agustus 24, 2021, dari Vaksin Sinovac: https://www.alodokter.com/vaksin-sinovac

INMENDAGRI. (2021, JUli 02). covid19.go.id. Dipetik Agustus 25, 2021, dari INMENDAGRI No 15 Tahun 2021 Tentang PPKM Darurat: https://covid19.go.id/storage/app/media/Regulasi/2021/Juli/INMENDAGRI\%2 0NO\%2015\%20TAHUN\%202021\%20TENTANG\%20PPKM\%20DARURAT. pdf

Investasi, K. K. (2021, Juli 25). PPKM Level Empat dan Tiga Diberlakukan Mulai 26 Juli-2Agustus 2021. Dipetik Agustus 23, 2021, dari maritim.co.id: https://maritim.go.id/ppkm-level-empat-tiga-diberlakukan-mulai-26-juli-2/

Lampung, K. (2021, Agustus 11). Kompas.tv. Dipetik Agustus 23, 2021, dari PPKM diperpanjang, Penyekatan Jalan Protokol Bandar Lampung Kembali dilakukan: https://www.kompas.tv/article/200744/ppkm-diperpanjang-penyekatan-jalanprotokol-bandar-lampung-kembali-dilakukan

Ramadhan, M. (2021, Juli 03). Kompas.com. Dipetik Agustus 2021, 23, dari Alasan Pemerintah terapkan PPKM darurat Jawa Bali: 2. https://www.kompas.com/tren/read/2021/07/03/083000865/resmi-berlaku-inialasan-pemerintah-terapkan-ppkm-darurat-jawa-bali

RI, K. K. (2020, Mei 26). apa saja kebijakan pemerintah indonesia di bidang kesehatan untuk penanganan covid 19. Dipetik Agustus 2021, 2021, dari djpb.kemenkeu.go.id: $\quad$ https://djpb.kemenkeu.go.id/kppn/tarakan/id/data- 
publikasi/berita-terbaru/2829-apa-saja-kebijakan-pemerintah-indonesia-dibidang-kesehatan-untuk-penanganan-covid-19.html

RI, K. K. (2021, Agustus 05). ekon.go.id. Dipetik Agustus 24, 2021, dari Pertumbuhan Ekonomi Triwulan II-2021 Menembus Zona Ekspansif: https://ekon.go.id/publikasi/detail/3196/pertumbuhan-ekonomi-triwulan-ii2021-menembus-zona-ekspansif

RI, K. K. (2021, Januari 13). p2p.kemkes.go.id. Dipetik Agustus 24, 2021, dari program vaksinasi covid-19 mulai dilakukan Presiden orang pertama penerima suntikan vaksin covid-19: http://p2p.kemkes.go.id/program-vaksinasi-covid-19-mulaidilakukan-presiden-orang-pertama-penerima-suntikan-vaksin-covid-19/

Rokom. (2021, Januari 18). sehat.negeriku.kemkes.go.id. Dipetik Agustus 24, 2021, dari pelaksanaa vaksinasi covid 19 Indonesia membutuhkan waktu 15 bulan: https://sehatnegeriku.kemkes.go.id/baca/rilis-

media/20210103/2536122/pelaksanaan-vaksinasi-covid-19-indonesiamembutuhkan-waktu-15-bulan/

Rokom. (2021, Januari 20). sehatnegeriku.kemkes.go.id. Dipetik Agustus 24, 2021, dari Enam Isu kesehatan jadi fokus kemenkes tahun 2021: https://sehatnegeriku.kemkes.go.id/baca/umum/20200814/1434631/enam-isukesehatan-jadi-fokus-kemenkes-tahun-2021/

Saputra, D. (2021, Agustus 06). Ekonomi.bisnis.com. Dipetik Agustus 23, 2021, dari ekonomi tumbuh 707 persen indef itu pertumbuhan semu: https:/ekonomi.bisnis.com/read/20210806/9/1426786/ekonomi-tumbuh-707persen-indef-itu-pertumbuhan-semu

Stastistik, B. P. (2021). bps.go.id. Dipetik Agustus 23, 2021, dari Publication: https://www.bps.go.id/publication/download.html?nrbvfeve=N2RINTlhMGE5 ODZiMjg2ZTkzMjlkMmY5\&xzmn=aHR0cHM6Ly93d3cuYnBzLmdvLmlkL3 B1YmxpY2F0aW9uLzIwMjEvMDgvMTkvN2R1NTlhMGE5ODZiMjg2ZTkz MjlkMmY5L2luZGlrYXRvci1rb25zdHJ1a3NpLS10cml3dWxhbi1pLTIwMjEu aHRtbA\%3D\%3D\&

Staststik, B. P. (2021, Agustus 05). bps.go.id. Dipetik Agustus 24, 2021, dari ekonomi Indonesia triwulan ii 2021 tumbuh 707 persen: https://www.bps.go.id/pressrelease/2021/08/05/1813/ekonomi-indonesiatriwulan-ii-2021-tumbuh-7-07-persen--y-on-y-.html

Wikipedia. (2020, September 11). id.wikipedia.org. Dipetik Agustus 24, 2021, dari Pembatasan sosial berskala besar $d$ Indonesia: https://id.wikipedia.org/wiki/Pembatasan_sosial_berskala_besar_di_Indonesia 